\title{
UJI EKSPERIMENTAL MESIN PENDINGIN BERPENDINGIN UDARA, DENGAN MENGGUNAKAN REFRIGERAN R22 DAN REFRIGERAN R407C
}

\author{
Kevin Sanjaya $^{1)}$, I Made Kartika Dhiputra ${ }^{2)}$ dan Harto Tanujaya ${ }^{1)}$ \\ ${ }^{1)}$ Program Studi Teknik Mesin, Fakultas Teknik Universitas Tarumanagara \\ ${ }^{2)}$ Departemen Teknik Mesin, Fakultas Teknik Universitas Indonesia \\ e-mail: kevinsanjaya95@yahoo.co.id
}

\begin{abstract}
Refrigerant $R 22$ can cause ozone layer depletion so that required refrigerant substitute for R22. Refrigerant $R 407 C$ is one of the refrigerant substitute for R22. Research of refrigerant in the cooling engine with air-cooled condenser is done by experimental methods. This research was conducted using refrigerants $R 22$ and refrigerant $R 407 C$ with a flow rate of $20 \mathrm{~L} / \mathrm{h}, 40 \mathrm{~L} / \mathrm{h}, 80 \mathrm{~L} / \mathrm{h}$ and $120 \mathrm{~L} / \mathrm{h}$. Test data processing include the calculation of refrigeration capacity, compressor power and COP values. COP or Coefficient Of Performance shows the efficiency of the refrigerant. The best COP values are in the refrigerant flow rate of $40 \mathrm{~L} / \mathrm{h}$, with R22 COP value of 5.818 and R407C COP value of 4.875 .
\end{abstract}

Keywords: R22, R407C, air cooled condenser, COP

\section{PENDAHULUAN}

Mesin-mesin pendingin pada saat ini semakin banyak dimanfaatkan seiring dengan kemajuan teknologi dan meningkatnya taraf hidup. Penggunaan mesin pendingin secara umum adalah untuk mendinginkan suatu ruangan dan mengawetkan makanan. Air conditioner (AC) adalah salah satu jenis mesin pendingin yang banyak digunakan dan dipasang di dalam rumah, apartemen maupun hotel. Tujuannya adalah untuk menurunkan temperatur di dalam suatu ruangan sehingga penghuni di dalam ruangan tersebut dapat merasa lebih nyaman.

Komponen utama pada mesin pendingin siklus refrigerasi kompresi uap antara lain: evaporator, kompresor, kondensor dan alat ekspansi. Kondensor pada mesin pendingin terbagi menjadi 2 jenis, yaitu air cooled condenser dan water cooled condenser. Jenis air cooled condenser banyak digunakan karena pemakaiannya yang lebih sederhana dan murah. Alat ekspansi pada mesin pendingin dapat menggunakan pipa kapiler atau katup ekspansi.

Media pendingin yang umumnya digunakan pada mesin pendingin di rumah tangga adalah refrigeran. Refrigeran adalah zat yang mengalir di dalam mesin pendingin. Zat ini berfungsi untuk menyerap panas dari benda atau udara yang didinginkan dan membawanya kemudian membuangnya ke udara sekeliling di luar benda/ruangan yang didinginkan. Mesin pendingin yang digunakan di rumah tangga umumnya menggunakan refrigeran tipe R22 sebagai fluida kerja.

Refrigeran tipe $\mathrm{R} 22\left(\mathrm{CHClF}_{2}\right)$ mengandung unsur klor $(\mathrm{Cl})$ yang dapat menimbulkan dampak negatif terhadap lingkungan. Unsur klor tersebut dapat mengikis lapisan ozon dengan cara mengikat atom $\mathrm{O}$ pada ozon $\left(\mathrm{O}_{3}\right)$ sehingga lapisan ozon akan terurai menjadi oksigen bebas $\left(\mathrm{O}_{2}\right)$. Hal ini meyebabkan lapisan ozon semakin menipis dan pancaran sinar ultraviolet akan semakin mudah masuk sehingga temperatur di bumi akan meningkat [2]. Oleh sebab itu, dibutuhkan refrigeran substitusi atau refrigeran pengganti yang lebih ramah lingkungan. Salah satu refrigeran pengganti R22 adalah refrigeran R407C. Refrigeran R407C merupakan campuran azeotrop antara $\mathrm{R} 32\left(\mathrm{CH}_{2} \mathrm{~F}_{2}\right) / \mathrm{R} 125\left(\mathrm{C}_{2} \mathrm{HF}_{5}\right) / \mathrm{R} 134 \mathrm{~A}\left(\mathrm{C}_{2} \mathrm{H}_{2} \mathrm{~F}_{4}\right)$ dengan komposisi 23/25/52 [1,2].

\section{PERUMUSAN MASALAH}

Penggunaan refrigeran R22 menyebabkan dampak negatif terhadap lingkungan seperti penipisan lapisan ozon dan peningkatan temperatur di bumi sehingga dibutuhkan refrigeran substitusi atau refrigeran pengganti yang ramah lingkungan [2]. Tujuan dari penelitian ini adalah untuk mengetahui nilai COP (Coefficient Of Performance) mesin pendingin dengan kondensor berpendingin udara yang menggunakan refrigeran R22 dan refrigeran R407C sebagai refrigeran pengganti R22.

Dalam penelitian ini, batasan masalah yang digunakan yaitu:

a. Kondensor yang digunakan berpendingin udara 
b. Alat ekspansi yang digunakan adalah katup ekspansi

c. Refrigeran yang digunakan adalah tipe R22 dan R407C

d. Pengukuran laju aliran refrigeran, temperatur T1 hingga T4, tekanan P1 hingga P4, dan kuat arus listrik.

\section{KAJIAN PUSTAKA}

Refrigerasi adalah metode pengkondisian temperatur ruangan agar tetap berada di bawah temperatur lingkungan. Karena temperatur ruangan yang terkondisi tersebut selalu berada di bawah temperatur lingkungan, maka ruangan akan menjadi dingin sehingga refrigerasi dapat juga disebut dengan metode pendinginan.

Siklus refrigerasi adalah siklus kerja yang mentransfer kalor dari media bertemperatur rendah ke media bertemperatur tinggi dengan menggunakan kerja dari luar sistem. Secara prinsip merupakan kebalikan dari siklus mesin kalor (heat engine). Dilihat dari tujuannya maka alat dengan siklus refrigerasi dibagi menjadi dua yaitu refrigerator yang berfungsi untuk mendinginkan media dan heat pump yang berfungsi untuk memanaskan media. Ilustrasi tentang refrigerator dan heat pump dapat dilihat pada Gambar 1.

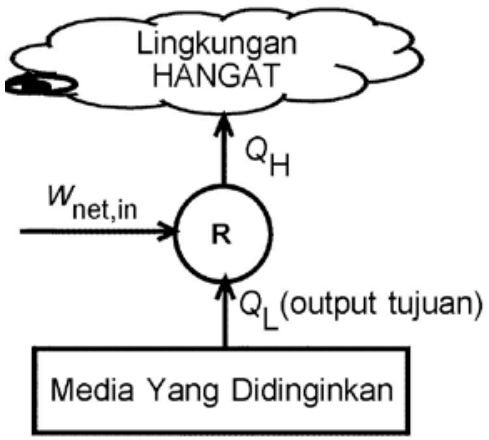

REFRIGERATOR
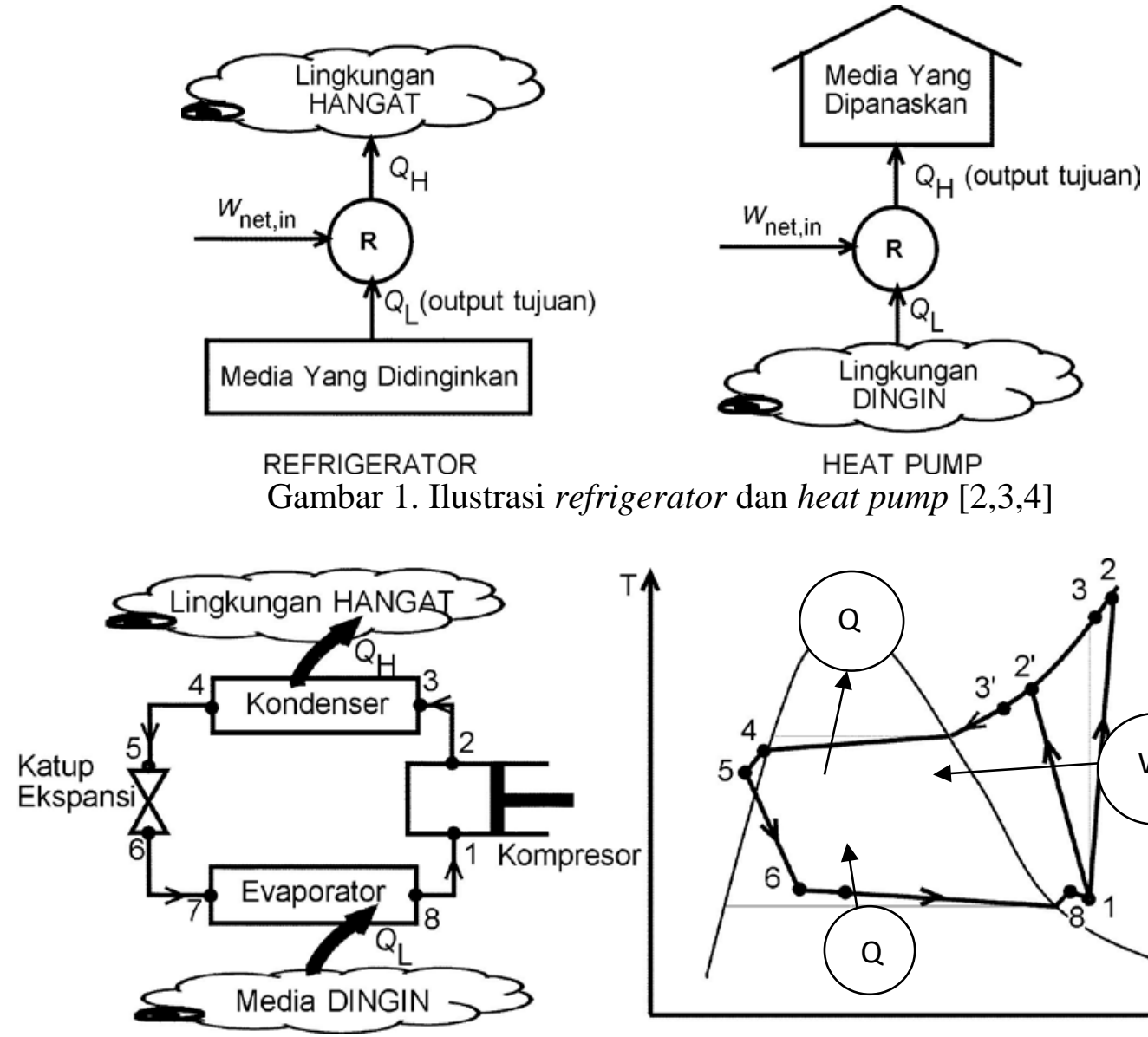

Gambar 1. Ilustrasi refrigerator dan heat pump [2,3,4]

Gambar 2. Siklus refrigerasi kompresi uap aktual [2,3,4]

Pada kenyataannya refrigerator atau heat pump akan bekerja dengan suatu proses yang menyimpang dari siklus idealnya akibat ireversibilitas dalam tiap komponennya. Ireversibilitas ini pada umumnya disebabkan oleh gesekan fluida dan perpindahan kalor dari atau ke lingkungan sekitar. Siklus refrigerasi kompresi uap aktual dapat digambarkan secara skematis seperti Gambar 2.

Hal-hal yang terjadi dalam siklus aktual pada Gambar 2:

a. Refrigeran sudah dalam kondisi uap panas lanjut sebelum masuk ke kompresor. 
b. Akibat cukup panjangnya pipa penghubung kompresor-evaporator akan mengakibatkan rugi tekanan. Rugi tekanan yang disertai peningkatan volume spesifik dari refrigeran membutuhkan power input yang lebih besar.

c. Dalam proses kompresi ada rugi gesekan dan perpindahan kalor yang akan meningkatkan entropi (1-2) atau menurunkan entropi (1-2') dari refrigeran tergantung kepada arah perpindahan kalornya. Proses (1-2') lebih disukai karena volume spesifiknya turun sehingga power input bisa lebih kecil. Hal ini bisa dilakukan apabila dilakukan pendinginan dalam langkah kompresi.

d. Di dalam kondensor akan terjadi juga rugi tekanan.

e. Refrigeran dalam kondisi cairan terkompresi ketika masuk dalam katup ekspansi.

Refrigeran adalah zat yang berfungsi sebagai media pendingin dengan menyerap kalor dari benda atau bahan lain seperti air atau udara ruangan, sehingga refrigeran tersebut dapat dengan mudah merubah fasanya dari cair menjadi gas. Sedangkan pada saat terjadinya pelepasan kalor oleh refrigeran terjadi perubahan fasa dari gas bertekanan tinggi jenuh menjadi cair.

Refrigeran R22 termasuk dalam kelompok refrigeran senyawa halokarbon. Kelompok refrigeran senyawa halokarbon diturunkan dari hidrokarbon $(\mathrm{HC})$ yaitu metana $\left(\mathrm{CH}_{4}\right)$, etana $\left(\mathrm{C}_{2} \mathrm{H}_{6}\right)$, atau dari propana $\left(\mathrm{C}_{3} \mathrm{H}_{8}\right)$ dengan mengganti atom-atom hidrogen dengan unsur-unsur halogen seperti khlor $(\mathrm{Cl})$, fluor $(\mathrm{F})$, atau brom $(\mathrm{Br})$. Jika seluruh atom hidrogen tergantikan oleh atom $\mathrm{Cl}$ dan $\mathrm{F}$ maka refrigeran yang dihasilkan akan terdiri dari atom khlor, fluor dan karbon. Refrigeran ini disebut refrigeran chlorofluorocarbon(CFC). Jika hanya sebagian saja atom hidrogen yang digantikan oleh $\mathrm{Cl}$ dan atau $\mathrm{F}$ maka refrigeran yang terbentuk disebut hydrochlorofluorocarbon (HCFC). Refrigeran halokarbon yang tidak mengandung atom khlor disebut hydrofluorocarbon (HFC).

Refrigeran R407C termasuk dalam kelompok refrigeran azeotropik. Kelompok refrigeran azeotropik adalah refrigeran campuran tak bereaksi yang tidak dapat dipisahkan dengan cara destilasi. Refrigeran ini pada konsentrasi, tekanan dan temperatur tertentu bersifat azeotropik, yaitu mengembun dan menguap pada temperatur yang sama, sehingga mirip dengan refrigeran tunggal. Namun demikian pada kondisi (konsentrasi, temperatur atau tekanan) yang lain refrigeran ini bisa saja menjadi bersifat zeotropik.

Sifat-sifat refrigeran yang harus dipenuhi untuk kebutuhan mesin pendingin adalah:

a. Tekanan penguapan harus cukup tinggi.

b. Tekanan pengembunan yang tidak terlampau tinggi.

c. Kalor laten penguapan harus tinggi.

d. Volume spesifik (terutama dalam fasa gas) yang cukup kecil.

e. Koefisien prestasi harus tinggi.

f. Konduktivitas termal yang tinggi.

g. Viskositas yang rendah dalam fasa cair maupun fasa gas. Dengan turunnya tahanan aliran refrigeran dalam pipa, kerugian tekanannya akan berkurang.

h. Refrigeran tidak boleh beracun dan berbau merangsang.

i. Refrigeran tidak boleh mudah terbakar dan mudah meledak

Rusaknya lapisan ozon disebabkan banyaknya zat-zat sintetik buatan manusia yang digunakan dalam berbagai aplikasi industri. Zat-zat yang umumnya berbentuk gas tersebut terlepas ke atmosfir dan merusak lapisan ozon yang ada di stratosfer. Zat yang dilepas di Indonesia dapat mengakibatkan rusaknya lapisan ozon di tempat lain. Dengan demikian masalah ini dianggap sebagai masalah global dan penanganannya juga harus dilakukan secara global dan bersama-sama oleh seluruh rakyat di berbagai negara. Zat-zat tersebut disebut Bahan Perusak Ozon (BPO). Diantara BPO tersebut adalah refrigeran CFC. Proses perusakan ozon oleh CFC diilustrasikan pada Gambar 3. 

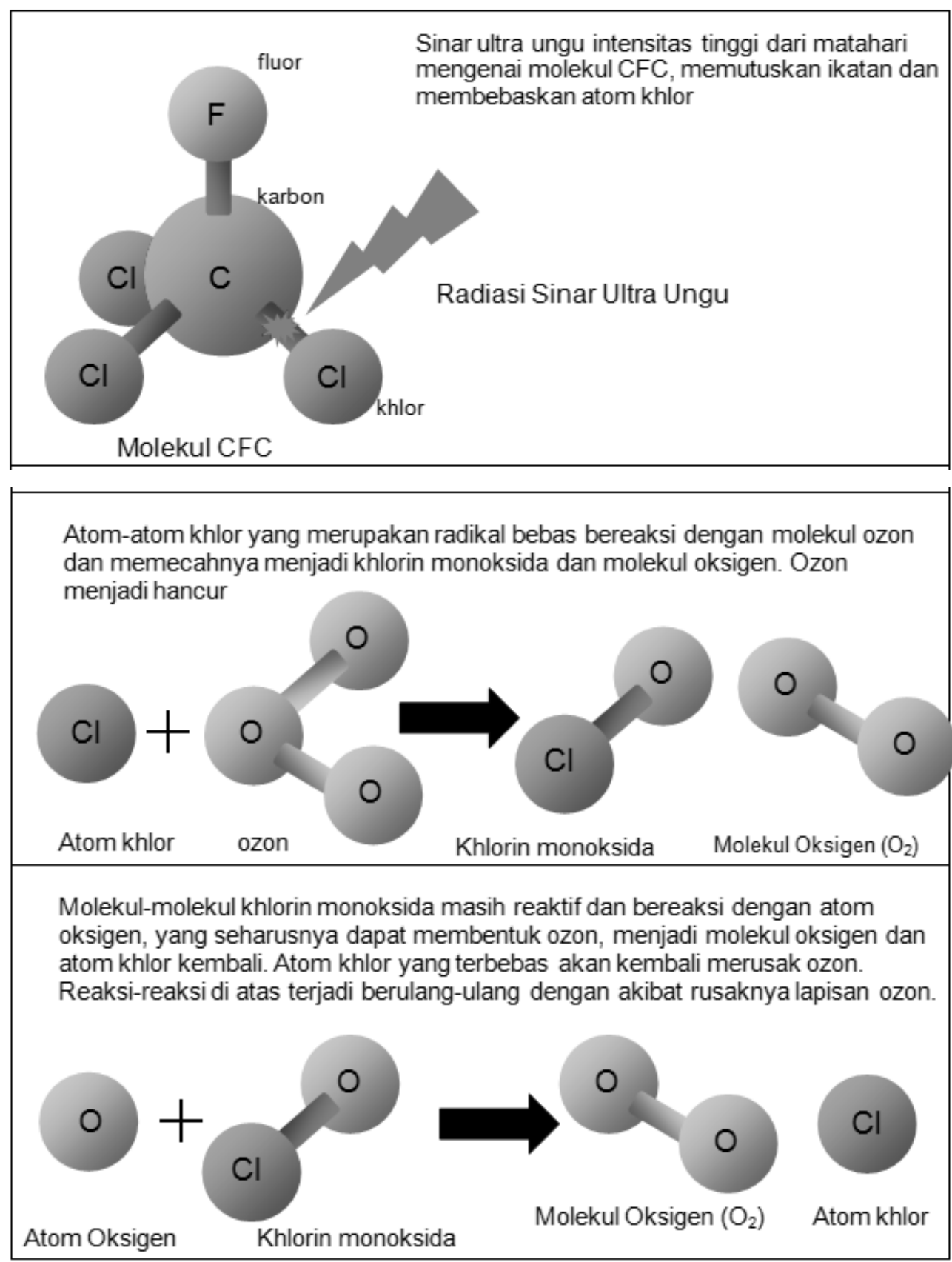

Gambar 3. Reaksi perusakan dan pencegahan pembentukan ozon [2]

Indonesia termasuk negara yang meyetujui konvensi-konvensi internasional dalam perlindungan lapisan ozon sejak tahun 1992. Karena Indonesia tidak memproduksi CFC, maka yang dimaksud dengan pengurangan konsumsi CFC pada dasarnya adalah pengurangan impor CFC. Telah banyak Keputusan Menteri Perindustrian dan Perdagangan yang mengatur tatacara impor Bahan Perusak Ozon (BPO). Dalam hal CFC Keputusan Menteri tersebut dapat diikhtisarkan sebagai:

a. Impor CFC hanya boleh dilakukan oleh importir terdaftar dan importir produsen.

b. Setelah tahun 2007 dilarang impor CFC.

c. Barang baru yang diproduksi di Indonesia dilarang menggunakan CFC. 


\section{METODOLOGI PENELITIAN}

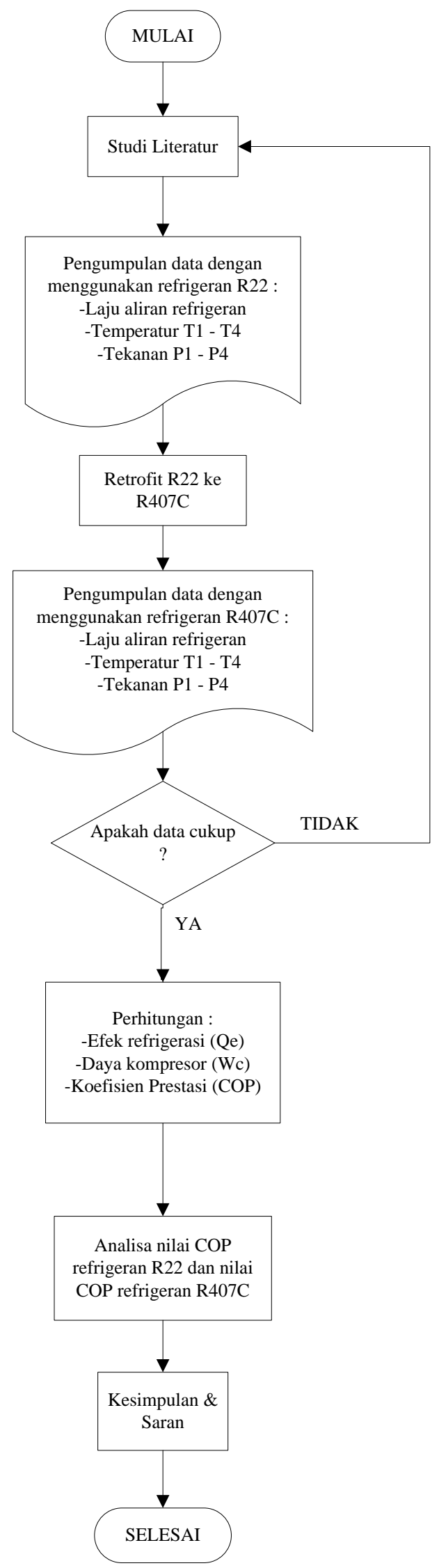

Gambar 4. Diagram alir pengerjaan penelitian 


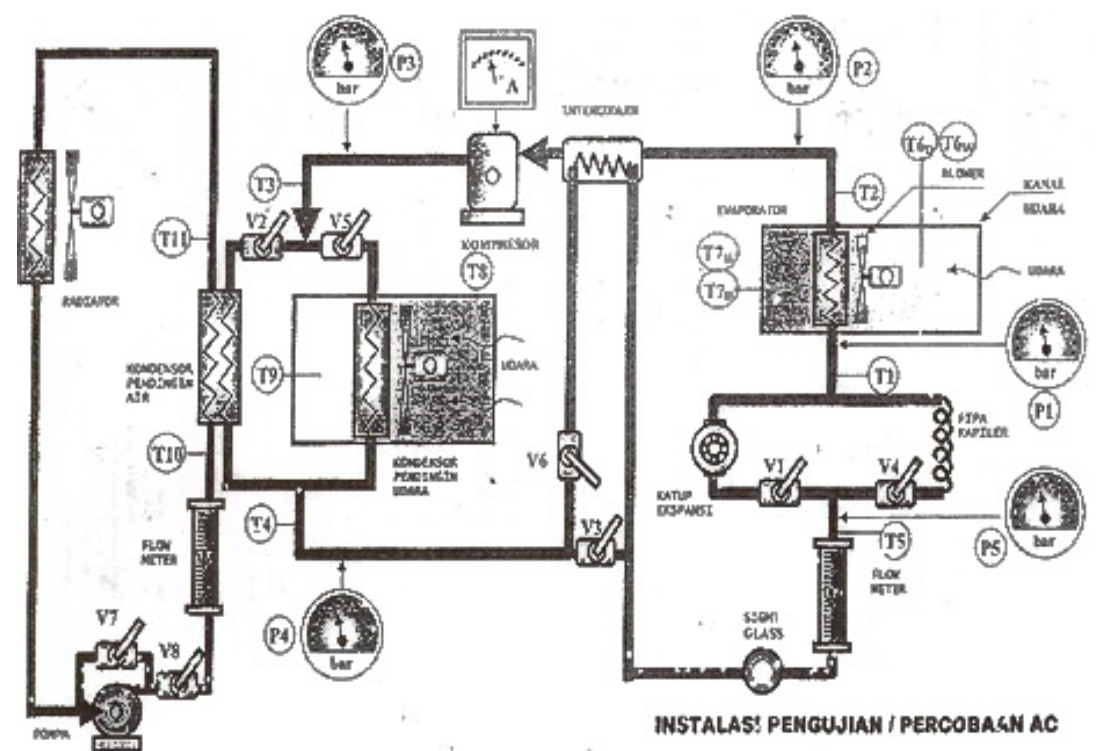

Gambar 5. Instalasi sistem mesin pendingin yang digunakan

Penelitian ini menggunakan mesin pendingin di Laboratorium Perpindahan Panas dan Massa Universitas Tarumanagara. Skema instalasi sistem mesin pendingin tersebut dapat dilihat seperti pada Gambar 5.

Dalam penelitian ini, dilakukan pengolahan data dengan melakukan perhitungan dari datadata yang telah didapatkan melalui uji eksperimental menggunakan persamaan di bawah ini [1]:

a. Besarnya laju perpindahan panas pada evaporator atau kapasitas refrigerasi (Qe)

$$
\dot{Q_{e}}=\dot{m}_{r}\left(h_{2}-h_{1}\right)
$$

b. Daya masukan kompresor (Wc)

$\dot{W}_{c}=\dot{m}_{r}\left(h_{3}-h_{2}\right)$

c. Koefisien prestasi (COP)

$$
C O P=\left(\frac{\dot{Q_{e}}}{\dot{W}_{c}}\right)=\left(\frac{\dot{m}_{r}\left(h_{2}-h_{1}\right)}{\dot{m}_{r}\left(h_{3}-h_{2}\right)}\right)=\frac{\left(h_{2}-h_{1}\right)}{\left(h_{3}-h_{2}\right)}
$$

Keterangan:

$\dot{m}_{r} \quad=$ besarnya laju aliran refrigeran yang dialirkan per satuan detik.

$\mathrm{h} \quad=$ nilai entalpi.

$\dot{Q}_{e} \quad=$ kapasitas refrigerasi yang dihasilkan oleh mesin pendingin.

$\dot{W}_{c} \quad$ = besarnya daya kompresor yang dibutuhkan untuk mengompres refrigeran.

COP = besarnya nilai koefisien peforma yang dihasilkan oleh mesin pendingin.

\section{HASIL DAN PEMBAHASAN}

Data hasil penelitian yang telah dilakukan dapat dilihat pada Tabel 1, 2, dan 3 di bawah:

\begin{tabular}{|c|c|c|c|c|c|c|c|c|c|}
\hline \multirow{2}{*}{ Flowrate } & \multicolumn{4}{|c|}{ Temperatur $\left({ }^{\circ} \mathrm{C}\right)$} & \multicolumn{4}{|c|}{ Tekanan (bar) } & \multirow{2}{*}{ Kuat Arus } \\
\hline & $\mathrm{T} 1$ & $\mathrm{~T} 2$ & T3 & $\mathrm{T} 4$ & P1 & $\mathrm{P} 2$ & P3 & $\mathrm{P} 4$ & \\
\hline $20 \mathrm{~L} / \mathrm{h}$ & -20 & 17 & 56 & 29 & 0,9 & 0,5 & 13 & 11,5 & $3,8 \mathrm{~A}$ \\
\hline $40 \mathrm{~L} / \mathrm{h}$ & -16 & 17 & 79 & 29 & 1,3 & 0,8 & 13 & 11,3 & $4,4 \mathrm{~A}$ \\
\hline $80 \mathrm{~L} / \mathrm{h}$ & -7 & 18 & 85 & 28 & 2,4 & 1,2 & 13 & 11,3 & $4,7 \mathrm{~A}$ \\
\hline $120 \mathrm{~L} / \mathrm{h}$ & -3 & 18 & 87 & 28 & 2,8 & 1,6 & 13 & 11 & $4,8 \mathrm{~A}$ \\
\hline
\end{tabular}

Tabel 1. Data hasil pengujian R22 
Tabel 2. Data hasil pengujian R407C

\begin{tabular}{cccccccccc}
\hline \multirow{2}{*}{ Flowrate } & \multicolumn{3}{c}{ Temperatur $\left({ }^{\circ} \mathrm{C}\right)$} & \multicolumn{5}{c}{ Tekanan (bar) } & \multirow{2}{*}{ Kuat Arus } \\
\cline { 2 - 8 } & $\mathrm{T} 1$ & $\mathrm{~T} 2$ & $\mathrm{~T} 3$ & $\mathrm{~T} 4$ & $\mathrm{P} 1$ & $\mathrm{P} 2$ & $\mathrm{P} 3$ & $\mathrm{P} 4$ & \\
\hline $20 \mathrm{~L} / \mathrm{h}$ & -17 & 15 & 58 & 30 & 1,3 & 1 & 14,1 & 12,4 & $4,7 \mathrm{~A}$ \\
$40 \mathrm{~L} / \mathrm{h}$ & -11 & 15 & 76 & 32 & 1,9 & 1,45 & 14,9 & 12,9 & $5,2 \mathrm{~A}$ \\
$80 \mathrm{~L} / \mathrm{h}$ & -2 & 16 & 83 & 34 & 3,15 & 2,35 & 15,5 & 13,3 & $5,7 \mathrm{~A}$ \\
$120 \mathrm{~L} / \mathrm{h}$ & 0 & 16 & 82 & 34 & 3,8 & 2,7 & 16 & 13,5 & $5,9 \mathrm{~A}$ \\
\hline
\end{tabular}

Tabel 3. Data hasil perhitungan

\begin{tabular}{cccccc}
\hline $\begin{array}{c}\text { Tipe } \\
\text { Refrigeran }\end{array}$ & $\begin{array}{c}\text { Flowrate } \\
(\mathrm{L} / \mathrm{h})\end{array}$ & $\begin{array}{c}\text { Density } \\
(\mathrm{kg} / \mathrm{L})\end{array}$ & $\begin{array}{c}\mathrm{Q}_{\mathrm{e}} \\
(\mathrm{kJ} / \mathrm{s})\end{array}$ & $\begin{array}{c}\mathrm{W}_{\mathrm{c}} \\
(\mathrm{kJ} / \mathrm{s})\end{array}$ & COP \\
\hline \multirow{4}{*}{$\mathrm{R} 22$} & 20 & 1,175 & 1,260 & 0,085 & 14,846 \\
& 40 & 1,175 & 2,507 & 0,444 & 5,818 \\
& 80 & 1,179 & 5,030 & 0,943 & 5,486 \\
$\mathrm{R} 407 \mathrm{C}$ & 120 & 1,179 & 7,546 & 1,493 & 5,186 \\
& 20 & 1,1129 & 1,212 & 0,130 & 9,333 \\
& 40 & 1,1034 & 2,393 & 0,491 & 4,875 \\
& 120 & 1,0955 & 4,723 & 1,120 & 4,217 \\
\hline
\end{tabular}

Grafik hasil perhitungan dapat dilihat pada Gambar 6, 7, dan 8 di bawah ini:

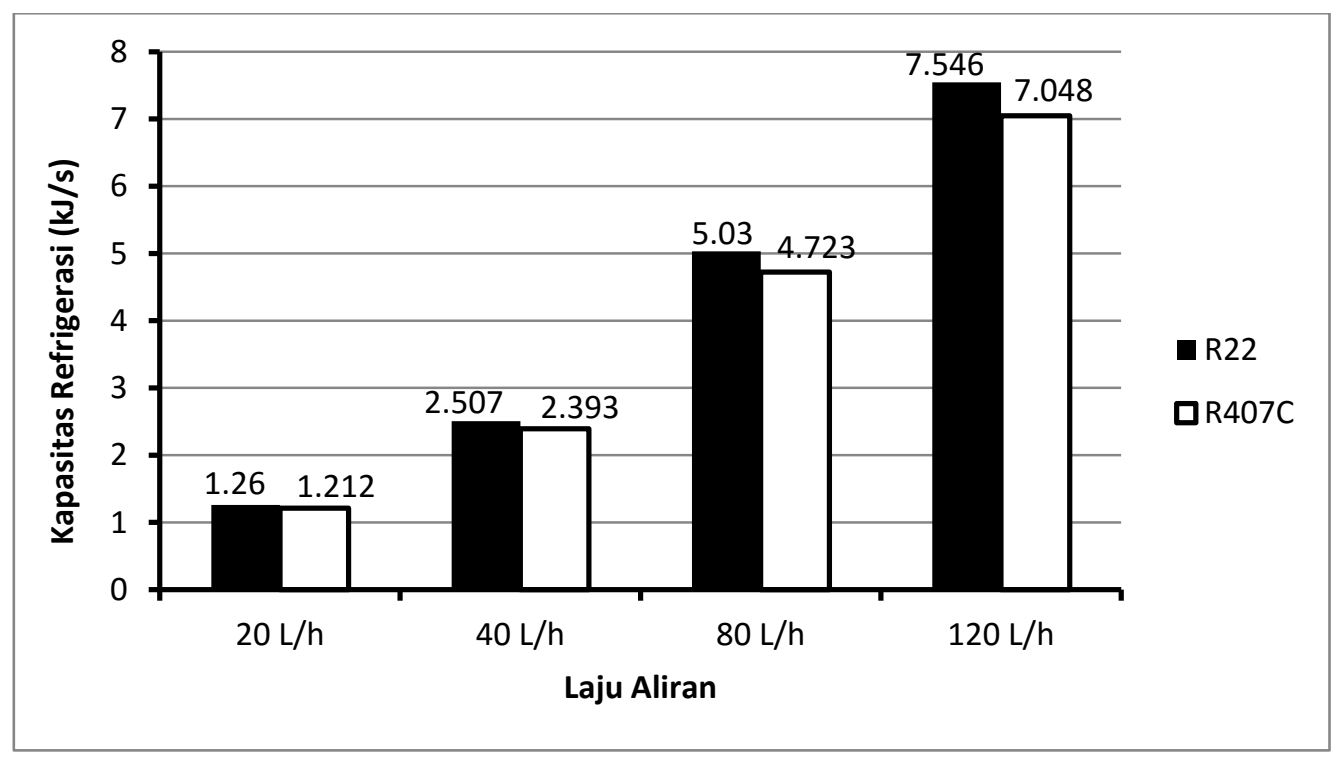

Gambar 6. Grafik kapasitas refrigerasi refrigeran R22 dan R407C

Analisis terhadap hasil perhitungan dari data pengujian pada Gambar 6 dan 7 terlihat bahwa kenaikan laju aliran refrigeran menyebabkan kenaikan nilai kapasitas refrigerasi dan daya kompresor. Hal ini dikarenakan nilai kapasitas refrigerasi dan daya kompresor berbanding lurus dengan nilai laju aliran.

Pada Gambar 8 terlihat bahwa kenaikan laju aliran refrigeran menyebabkan penurunan nilai COP. Hal ini terjadi karena kenaikan daya kompresor pada setiap kenaikan laju aliran lebih besar dibandingkan kenaikan kapasitas refrigerasi.

Nilai COP R407C lebih rendah daripada nilai COP R22 pada setiap laju aliran. Hal ini dikarenakan perbedaan tekanan P3 - P2 untuk refrigeran R407C lebih tinggi daripada refrigeran R22 dan perbedaan tekanan P1 - P2 untuk refrigeran R407C lebih rendah daripada refrigeran R22 
sebagaimana dapat dilihat pada Tabel 3 sehingga efektivitas kompresi pada refrigeran R22 menjadi lebih baik.

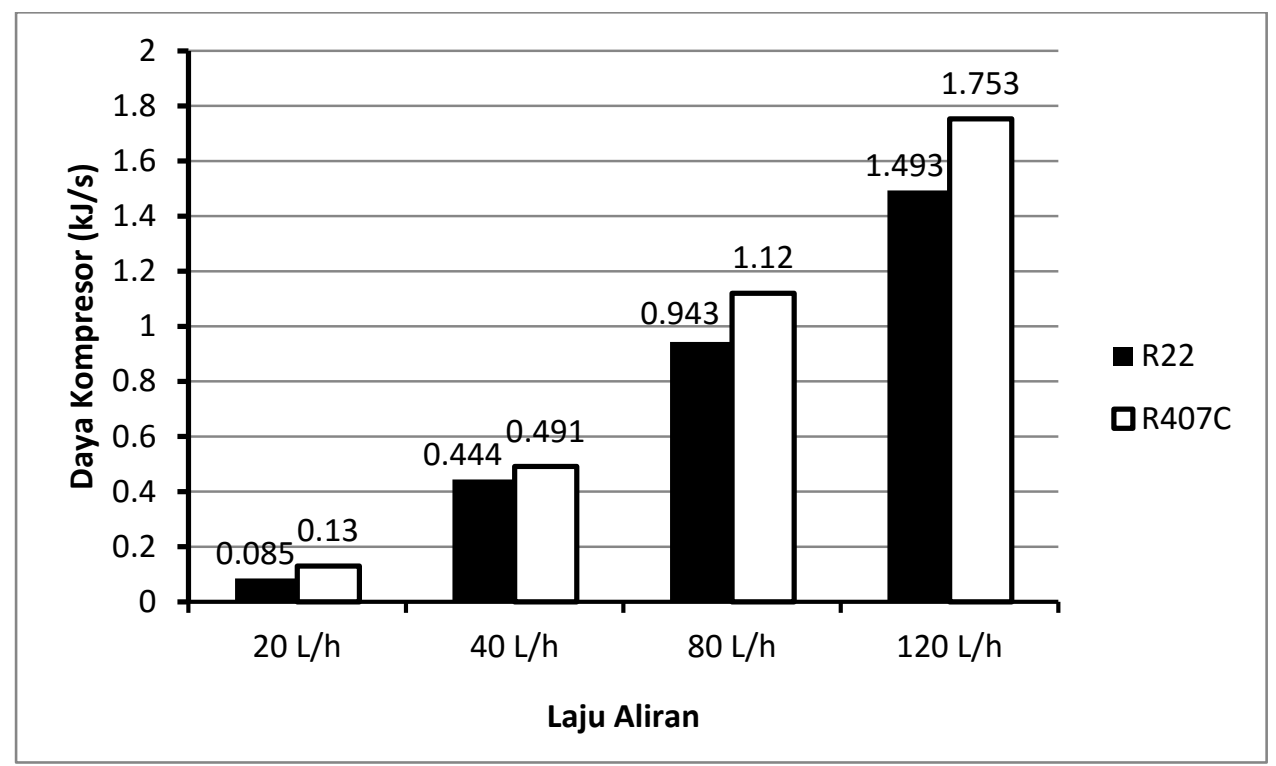

Gambar 7. Grafik daya kompresor refrigeran R22 dan R407C

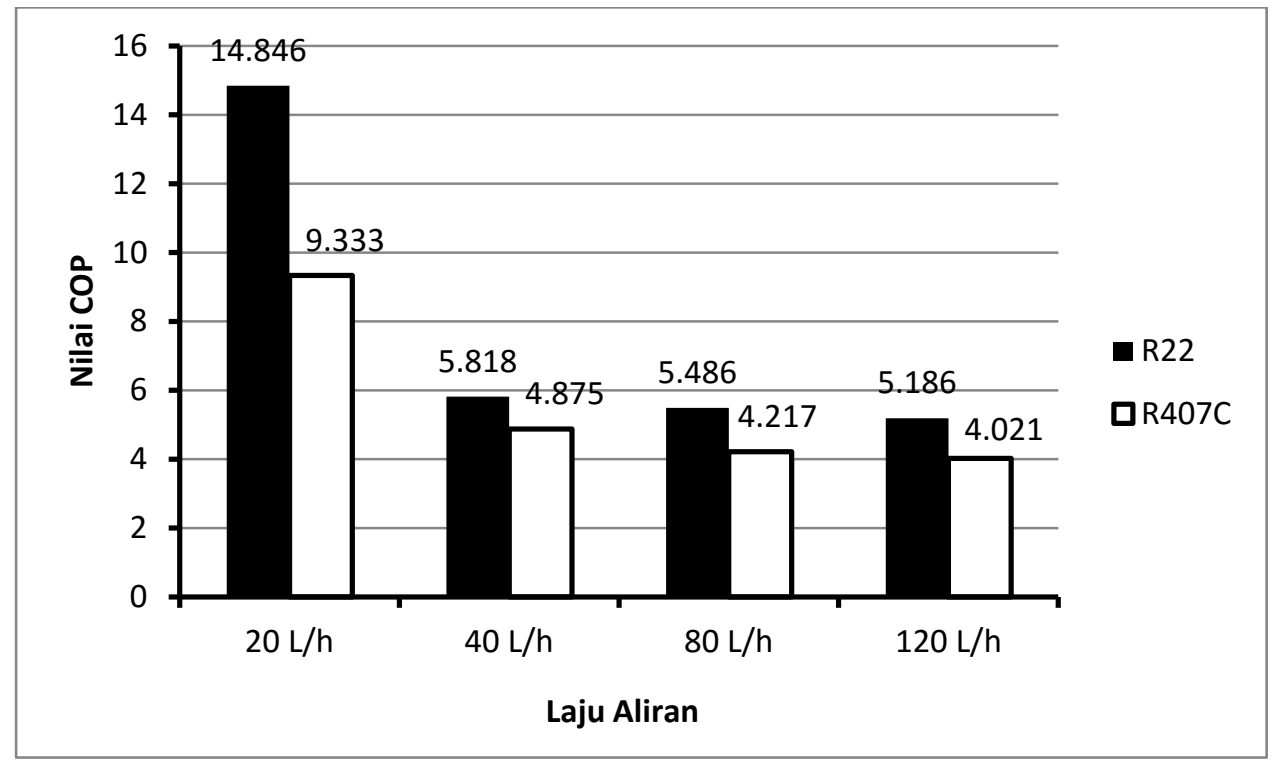

Gambar 8. Grafik COP refrigeran R22 dan R407C

Pada Gambar 8 juga terlihat bahwa COP refrigeran R22 dan refrigeran R407C pada laju aliran $20 \mathrm{~L} / \mathrm{h}$ memiliki nilai yang sangat tinggi dan berbeda jauh dibandingkan nilai COP pada laju aliran lainnya. Hal ini dikarenakan nilai entalpi h3 pada laju aliran $20 \mathrm{~L} / \mathrm{h}$ lebih rendah daripada yang seharusnya. Pada laju aliran $20 \mathrm{~L} / \mathrm{h}$, refrigeran yang keluar dari evaporator masih berada dalam fasa cair akibat laju aliran refrigeran yang terlalu kecil dan menyebabkan kompresor bekerja dengan tidak sempurna yang berdampak pada penurunan nilai temperatur dan tekanan kompresor sehingga nilai h3 pada laju aliran $20 \mathrm{~L} / \mathrm{h}$ menjadi lebih rendah.

Dari hasil perhitungan yang telah dilakukan, diperoleh nilai COP tebaik berada pada laju aliran $40 \mathrm{~L} / \mathrm{h}$ baik untuk refrigeran R22 maupun refrigeran R407C. Alasannya adalah nilai COP pada laju aliran $40 \mathrm{~L} / \mathrm{h}$ lebih tinggi dibandingkan nilai COP pada laju aliran $80 \mathrm{~L} / \mathrm{h}$ dan laju aliran $120 \mathrm{~L} / \mathrm{h}$. Nilai COP pada laju aliran $20 \mathrm{~L} / \mathrm{h}$ baik dari pengujian refrigeran R22 maupun dari 
pengujian refrigeran R407C sangat tinggi, akan tetapi nilai tersebut diperoleh dalam kondisi sistem yang tidak sempurna. Dikatakan dalam kondisi sistem yang tidak sempurna karena refrigeran yang masuk ke dalam kompresor pada laju aliran $20 \mathrm{~L} / \mathrm{h}$ masih berada dalam fasa cair. Hal ini menyebabkan tekanan dalam kompresor turun sehingga kompresor bekerja dengan tidak sempurna dan mengakibatkan nilai COP yang dihasilkan tidak tepat. Oleh karena itu, nilai COP terbaik dalam kondisi sistem yang stabil adalah pada laju aliran refrigeran $40 \mathrm{~L} / \mathrm{h}$.

\section{KESIMPULAN DAN SARAN}

Nilai COP terbaik dari pengujian yang telah dilakukan berada pada laju aliran refrigeran 40 L/h, baik untuk refrigeran R22 maupun refrigeran R407C. Nilai COP terbaik pada mesin pendingin dengan kondensor berpendingin udara yang menggunakan refrigeran R22 adalah sebesar 5,818 dan nilai COP terbaik pada mesin pendingin dengan kondensor berpendingin udara yang menggunakan refrigeran R407C adalah sebesar 4,875.

Walaupun refrigeran R407C tidak merusak lingkungan dibandingkan refrigeran R22, akan tetapi nilai COP refrigeran R407C yang diperoleh dari hasil pengujian lebih rendah daripada nilai COP refrigeran R22. Oleh karena itu, perlu dilakukan pengujian terhadap refrigeran substitusi lainnya seperti R410A hingga diperoleh refrigeran pengganti R22 yang memiliki nilai COP yang hampir sama dengan refrigeran R22.

\section{DAFTAR PUSTAKA}

[1] ASHRAE. (1985). Handbook of Fundamentals, Society of Heating, Refrigerating, and Air Conditioning Engineers. ASHRAE. Atlanta.

[2] Institut Teknologi Bandung. (2003). TOT For Refrigeration Technician. Institut Teknologi Bandung. Bandung.

[3] Rohmat, Tri Agung. (2000). Termodinamika Lanjut. Universitas Gajah Mada. Yogyakarta.

[4] Stoecker, Wilbert F. (1992). Refrigerasi dan Pengkondisian Udara, Edisi Kedua. Erlangga. Jakarta.

[5] Whitman, Bill, dkk. (2012). Refrigeration \& Air Conditioning Technology, 7th ed. Cengage Learning. Canada. 